\title{
Application of Markowitz Model on Romanian Stock Market
}

\author{
Ioana Coralia ZAVERA, \\ The Bucharest University of Economic Studies, \\ 6 Piata Romana, $1^{\text {st }}$ District, Bucharest, 010374, Romania \\ zaveraioanacoralia@yahoo.com
}

\begin{abstract}
Performance evaluation of financial instruments has become a concern for more and more economists, while security trading activities have developed over time. "Modern portfolio theory" comprises statistical and mathematical models which describe various ways in order to evaluate and especially analyse profitability and risk of these portfolios. This article offers an application of this type of model on Romanian stock market, the Markowitz model, by focusing on portfolios comprising three securities, and determining the efficient frontier and the minimum variance portfolio.
\end{abstract}

Keywords: probability; risk; return; minimum variance portfolio; efficient frontier

JEL Classification: F3, G1, G2.

\section{Introduction}

Harry Markowitz, developed a theory for portfolio selection, which was later enhanced into modern portfolio theory. He was also awarded in Economic Sciences for his "pioneering work in the theory of financial economics". Before this theory, other models, such as securities selection, concentrated on investment opportunities, specifically on returns generated by them. The main approach of standard investments was identifying those titles that offer the best earning opportunities and at the same time the lowest risk, and then building a portfolio based on such titles. An investor could, for example, consider that all equities in the railway industry offer good risk-return ratio and as such he might build a portfolio consisting only of these stocks. While Markowitz' theory insists on return, it also gives equal importance to risk, hence the risk of the portfolio ${ }^{1}$ became a new research topic. 
Although the risk had been previously considered a significant factor and the variance was deemed as an appropriate variable to risk measures ${ }^{2}$, the first who demonstrate clearly and rigorously how the portfolio variance can be reduced by diversification was Markowitz. He suggested that in selecting a portfolio investors should focus on the general aspects, the overall features of risk-return ratio, rather than choosing portfolios consisting in securities with attractive individual risk-return ratio.

When applying the Markowitz model, the portfolio risk for an expected given return cannot be reduced by diversification (or any expected return ${ }^{3}$ cannot be achieved without increasing portfolio risk). The set of all portfolios with expected returns that achieve maximum value at a certain level of risk represents efficiency frontier.

The underlying assumptions regarding investors' behaviour and financial markets in the Markowitz model are:

1. It is possible to estimate a probability law in regards to the distribution of returns for the duration of owning/possessing the securities.

2. Investors focus on maximizing utility, while also taking into account their risk aversion.

3. Possible values of returns are used to measure risk.

4. The choice of investors is based on two points of return distribution, mean and variance of a portfolio over a certain period of time.

5. Return is desirable, and risk should be avoided.

This research sets out to apply the model on Romanian stock market by taking into account three listed assets, with daily prices, during 2010-2015 (OMV Petrom - energy, oil and gas sector; Transgaz - energy sector; Albalact - food sector, dairy industry). By applying this model, minimum variance portfolio will be determined.

Firstly, rate of returns ${ }^{4}$ of these three assets will be calculated, by using the formula:

$$
\mathrm{E}\left(\mathrm{R}_{\mathrm{t}}\right)=\frac{P_{t}-P_{t-1}}{P_{t-1}}
$$

Then, by applying Descriptive Statistics function in Excel, we find the mean value of returns for each of these three securities, and also the standard deviation $^{5}$, as shown in Table 1. 
Table 1. Rate of returns and standard deviations of three assets

\begin{tabular}{ccc}
\hline & Rate of return & Standard deviation \\
\hline OMV Petrom & 0.00023477 & 0.016557547 \\
Transgaz & 0.000466178 & 0.01431687 \\
Albalact & 0.000138089 & 0.020075393 \\
\hline
\end{tabular}

Source: author's calculations

The set of all possible portfolios, also known as achievable set, can be built (shown in Figure 1). An efficient portfolio is a portfolio which offers the maximum return possible for any degree of risk or the minimum risk degree possible for any estimated return. This can be achieved, as was done for this research, by using Random function from Excel in order to generate probabilities, followed by computing/calculating returns (1) and standard deviations (2) using the formulas:

$$
\text { (1) } E\left(r_{p}\right)=w_{a} E\left(r_{a}\right)+w_{b} E\left(r_{b}\right)+w_{c} E\left(r_{c}\right)
$$

(2) $\sigma^{2}\left(\mathrm{r}_{\mathrm{p}}\right)=\sum_{i=1}^{n} w_{i} \sigma^{2}\left(r_{i}\right)+\sum_{i=1}^{n} \sum_{j=i+1}^{n} 2 w_{i} w_{j} \operatorname{cov}\left(r_{i}, r_{j}\right) ; \sigma\left(\mathrm{r}_{\mathrm{p}}\right)=\sqrt{\sigma^{2}\left(\mathrm{r}_{\mathrm{p}}\right)}$

Figure 1. The set of all portfolios obtained by combining the three assets

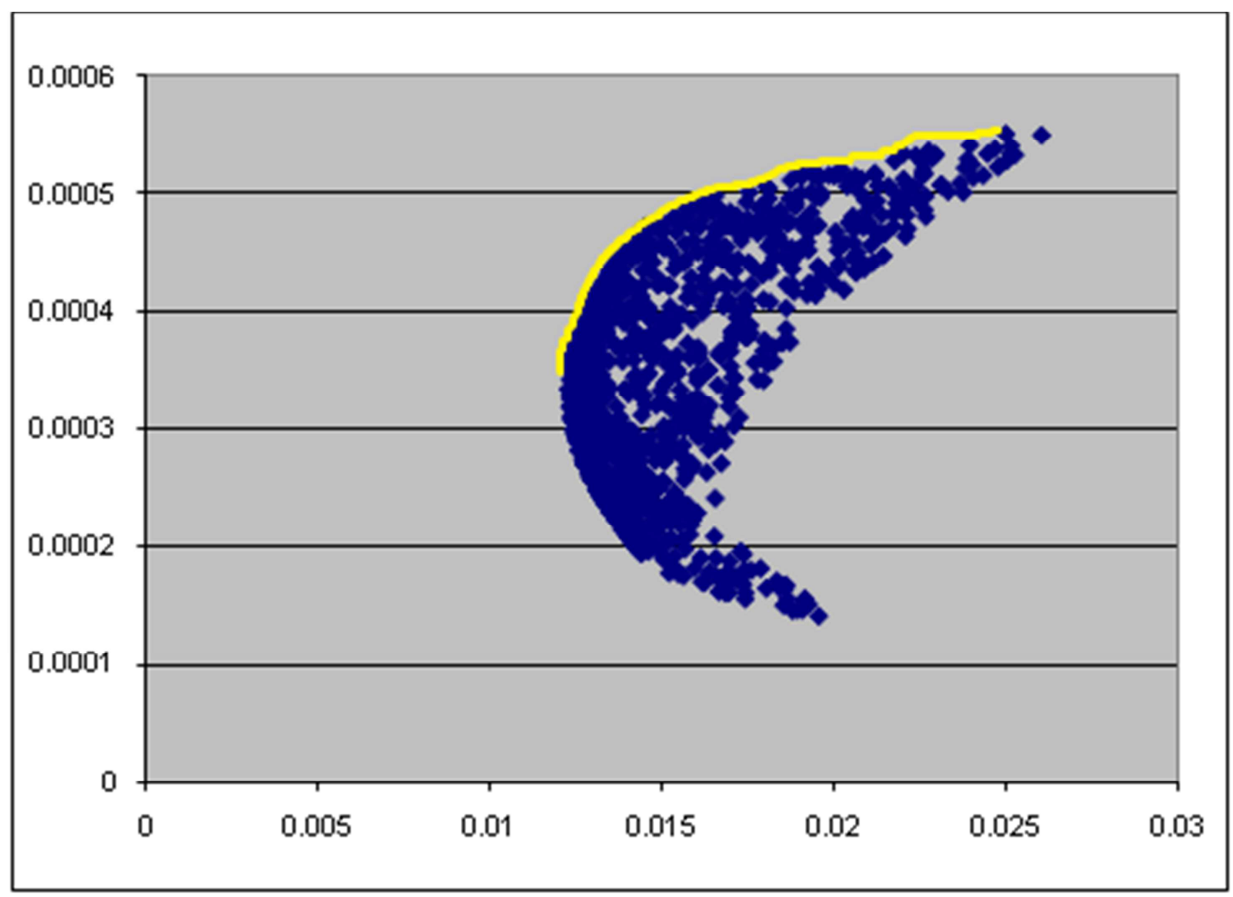

Source: author's calculations 
It is important to mention that not all these portfolios are actual choices for investors or companies; the frontier (the yellow line in the graphic) defines the set of efficient portfolios, the portfolios from the left side of the efficient set are not possible, as no set of return values exists, and those from the right side are inefficient as for each of them it is possible to choose another portfolio with a higher rate of return at the same risk degree or a lower risk having the same rate of return.

In order to find the minimum variance portfolio, consisting of three assets (OMV Petrom, Transgaz and Albalact) we start from the assumption that the shares of investments in each portfolio are equal, namely $0.333\left(\sum_{i=1}^{n} w_{i}=1\right)$. Portfolio return is calculated according to the formula $\mu=\left(w_{a}, w_{b}, w_{c}\right) \times\left(\begin{array}{l}r_{a} \\ r_{b} \\ r_{c}\end{array}\right)$. For estimating the standard deviation ( $\sigma p)$ of our portfolio the variancecovariance matrix plays an important role. Starting from the return, the covariance can be calculated $\sigma_{\mathrm{xy}}=\frac{1}{n} \sum_{i=1}^{n}\left(x_{i}-\bar{x}\right)\left(y_{i}-\bar{y}\right)$, then by using formula $\sum_{k \times k}=\left(\frac{1}{n}\right) X^{T} X$ the matrix will be formed, as shown in the table below. For the portfolio expected return and standard deviation, we used the function Matrix Multiplication.

Table 2. Covariance matrix

\begin{tabular}{cccc}
\hline & OMV Petrom & TRANSGAZ & ALBALACT \\
\hline OMV Petrom & 0.000273977 & $9.88062 \mathrm{E}-05$ & $9.23445 \mathrm{E}-05$ \\
TRANSGAZ & $9.88062 \mathrm{E}-05$ & 0.000204842 & $9.17936 \mathrm{E}-05$ \\
ALBALACT & $9.23445 \mathrm{E}-05$ & $9.17936 \mathrm{E}-05$ & 0.000402764 \\
\hline
\end{tabular}

Source: author's calculations

Taking into account the lowest standard deviation from the three assets (0.0143 - Transgaz), the expected return can be maximized. For this, Solver function from Excel will be used, with two conditions: the sum of shares remains the same $(0.999 \approx 1)$, and the standard deviation is equal with or less than 0.0143 .

For a minimum variance portfolio, it is necessary to find, by using the same Solver function, a minimum standard deviation with the changed shares and rate of return, and by modifying the second condition: the expected return must be equal or higher than Transgaz rate of return $(0.000466$ - the highest from all three indices). The results show that the asset with the lowest standard 
deviation brings the maximum return for the investor, while for the maximum expected return the investor builds his portfolio with only Transgaz assets in order to assume the lowest risk degree. Sharpe Ratio is also calculated as the ratio between return and standard deviation, and this indicator shows the additional gain based on risk (Table 3 ).

Table 3. Minimum variance portfolio

\begin{tabular}{ccccc}
\hline & & & & \\
& & max return & $\begin{array}{c}\text { min std, } \boldsymbol{\mu} \text { >=return } \\
\text { TRANSGAZ }\end{array}$ & $\begin{array}{c}\text { min std, } \\
\text { return }>=0\end{array}$ \\
\hline MV Petrom & 0.3333 & 0 & 0 & 0.305056828 \\
TRANSGAZ & 0.3333 & 0.999 & 0.999999995 & 0.504941122 \\
ALBALACT & 0.3333 & 0 & 0 & 0.189902047 \\
\multicolumn{1}{c}{ sum } & 0.9999 & 0.999 & 0.999999995 & 0.999899997 \\
$\mu \quad 0.000279651$ & 0.000465711 & 0.000466178 & 0.000333234 \\
op & 0.012680615 & 0.014297983 & 0.014312295 & 0.01228785 \\
Sharpe ratio & 0.022053424 & 0.032571822 & 0.032571822 & 0.027118974 \\
\hline
\end{tabular}

Source: author's calculations

Thus, the minimum variance portfolio has a standard deviation of $1.43 \%$, for a maximum expected return of $0.046 \%$. However, when the condition is that shares are equal to or higher than 0 , without a maxim return restriction, the risk will be $1.22 \%$, the largest share of the portfolio consisting also in Transgaz securities. Sharpe Ratio also records the higher value in those two situations (0.032).

Minimum variance portfolio can be plotted, having as coordinates (0.000466178; 0.014312295). 
Figure 2. Minimum variance portfolio

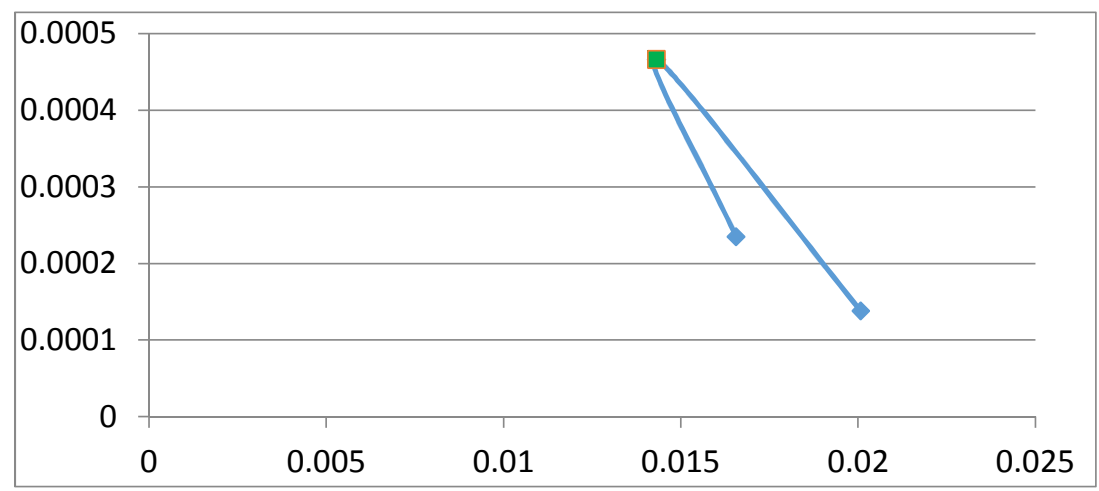

Source: author's interpretation

We can observe that minimum variance portfolio has an expected return of $0.046 \%$, with risk taking of $1.43 \%$ and Sharpe Ratio of 3.2 , and the investor will choose a portfolio with Transgaz assets.

\section{Conclusions}

The analysis of a portfolio with Transgaz securities justifies the price difference between these and OMV Petrom and Albalact securities. The lack of information about prices of securities from Romanian stock market makes building a portfolio by using the Markowitz model an imperfect and difficult decision making process. The data used for this research shows a very slow evolution of equity prices, resulting in null or negative returns.

The portfolio obtained using Markowitz model with three assets can be considered illegitimate, considering that the optimization of possessing securities did not account for the possibility to make other investments, as in risk free assets.

Markowitz model allows building an absolute minimum variance portfolio, which considers the combination of assets that offers the lowest level of risk, and the efficiency frontier that encompasses the optimal portfolios held by investors. A limit of this model consists of not taking into account the influence of macroeconomic factors on return and risk. 


\section{References}

[1] Anghelache, G. V., \& Anghel, M. G. (2013). Modele specifice în analiza portofoliului, Economie teoretică şi aplicată, Volumul XX, No. 11(588), pp. 4-22.

[2] Anghelache, G., \& Anghelache, C. (2014). Diversifying the risk through portfolio investment, Theoretical and Applied Economics, vol. XXI, no.9 (598), pp. 7-22.

[3] Badea, L. (2006), Studiu asupra aplicabilității modelului Markowitz pe piața bursieră din România, Economie Teoretică și Aplicată, 9(504), pp.21-24.

[4] LeRoy, S. F., \& Werner, J. (2001). Principles of financial economics, Cambridge: University Press.

[5] Markowitz, H. M. (1952). Portfolio Selection, Journal of Finance, vol. 7, pag. 77-91.

[6] Marling, H. \& Emanuelsson, S. (2012), The Markowitz Portfolio Theory, available at http://www.math.chalmers.se/ rootzen/finrisk/gr1_HannesMarling_SaraEmanuelsson_MPT .$p d f$

[7] Miloș, L.R., \& Miloș, M.C. (2014). Construction pf a Financial Portfolio on the Bucharest Stock Exchange using reisk/return Analysis, Annales Universitatis Apulensis Series Oeconomica, 16(2), pp. 212-220.

[8] Nielsen, A.G., \& Vladimarsson, G.Z. (2011). How to create portfolios for different risk groups and what to consider, Aarhus School of Business and Social Sciences, Department of business studies.

[9] Stancu, I., \& Stancu, D. (2012). Finanţe corporative cu Excel, București: Ed. Economică.

[10] Viju, C., et. al. (2004). Portfolio optimization using markowitz model: an application to the Bucharest Stock Exchange, Supply chain and finance, pp. 229-251.

[11] Zhou, Y., \& Yin, G. (2006). Markowitz's Mean-Variance Portfolio Selection with Regime Switching: A Continuous-Time Model, SIAM Journal on Control and Optimization, vol. 42 (4), pp.1466-1482.

[12] www.bvb.ro

[13] http://www.nobelprize.org/nobel_prizes/economic-sciences/laureates/1990/markowitzfacts.html, Harry M. Markowitz - Facts, Nobelprize.org. Nobel Media AB 2014. Web. 19 Apr 2016.

[14] http://www.investopedia.com/

Endnotes

\footnotetext{
${ }^{1} \mathrm{http} / / / \mathrm{www}$.investopedia.com/exam-guide/series-66/portfolio-risks/measuring-portfolio-risks.asp

${ }^{2} \mathrm{http}: / / \mathrm{www}$.investopedia.com/terms/r/riskmeasures.asp

${ }^{3} \mathrm{http}: / / \mathrm{www}$. investopedia.com/terms/e/expectedreturn.asp

${ }^{4} \mathrm{http}: / / \mathrm{www}$.investopedia.com/terms/r/rateofreturn.asp

${ }^{5} \mathrm{http} / / / \mathrm{www}$.investopedia.com/terms/s/standarddeviation.asp
} 